WERONIKA KLON

ORCID 0000-0001-8657-0597

Szkoła Podstawowa nr 4 im. Jana Brzechwy

w Swarzędzu

KATARZYNA WASZYŃSKA

ORCID 0000-0003-1495-4537

Uniwersytet im. Adama Mickiewicza

w Poznaniu

\title{
MINDFULNESS W PRACY Z DZIEĆMI I MŁODZIEŻĄ
}

\begin{abstract}
AвstRact. Klon Weronika, Waszyńska Katarzyna, Mindfulness w pracy z dziećmi i młodzieża [Mindfulness in Work with Children and Young People]. Studia Edukacyjne nr 57, 2020, Poznań 2020, pp. 103117. Adam Mickiewicz University Press. ISSN 1233-6688. DOI: $10.14746 /$ se.2020.57.8

The article addresses the assumptions of mindfulness in children training. It contains clues to the use of some techniques in different age groups. It shows what benefits of both teachers and students in Polish school from implement mindfulness in the school curriculum. These effects pertain to the education process and social functioning. The article moreover contains a description of limitations in the realization of mindfulness assumptions in the Polish education system.
\end{abstract}

Key words: mindfulness, mindfulness training, education

\section{Wprowadzenie}

Uważność (ang. Mindfulness) to podejście w nauce i praktyce psychologicznej funkcjonujące od lat siedemdziesiątych dwudziestego wieku. Pierwotny zarys tej koncepcji można jednak odnaleźć w wielu tradycyjnych podejściach do duchowości człowieka, między innymi buddyzmie, taoizmie, judaizmie, islamie, czy chrześcijaństwie ${ }^{1}$.

${ }^{1}$ R. Harris, Zrozumieć ACT. Terapia akceptacji i zaangażowania w praktyce, przekł. A. Sawicka-Chrapkowicz, Sopot 2017. 
Prekursorem uważności jest Jon Kabat-Zinn, który w 1979 roku na Uniwersytecie Medycznym w Massachusetts otworzył Centrum Uważności. Określił on mindfulness jako „receptywny stan świadomości, będący wynikiem ciągłego i celowego kierowania uwagi na to, co się dzieje w chwili obecnej, bez oceniania treści doświadczenia” ${ }^{2}$. To również „czysta i zwykła świadomość tego, co się faktycznie wydarza nam i w nas, w kolejnych chwilach postrzegania”’3. Oznacza „świadomość, która pojawia się poprzez zwracanie uwagi na cel, w chwili obecnej i bez osądu, na rozwój doświadczenia z chwili na chwilę" ${ }^{\prime \prime}$ ",świadomość bieżącego doświadczenia i jego akceptowanie" ${ }^{5}$. Jak podaje Adamik ${ }^{6}$, we wszystkich tych definicjach wskazuje się na trzy wspólne aspekty: intencjonalność (uwaga kierowana celowo), koncentrację na teraźniejszości oraz postawę akceptacji (bez oceniania). Można by powiedzieć, że dzięki temu zwiększa się świadomość przeżywania, odczuwania, doświadczania tego, co się wydarza.

Praktyka uważności polega na kierowaniu własnej uwagi w sposób elastyczny i otwarty na to, co aktualnie znajduje się w jej polu, bez osądzania obserwowanych treści. Czasem praktyka uważności może wydawać się zajęciem frustrującym, zwłaszcza przy pierwszych próbach wdrożenia jej w życie. Głównymi przyczynami tej frustracji nie jest jednak poziom jej skomplikowania lub ilość wysiłku poznawczego, jakiego wymaga, a jej tymczasowy charakter ${ }^{7}$. Nasz umysł ma naturalne tendencje do nieustannego oceniania i analizowania. Uwaga łatwo ulega rozproszeniu, a nasze myśli samoczynnie koncentrują się na ciągach przyczynowo-skutkowych ${ }^{8}$. Można to bez trudu zauważyć, kiedy poszukujemy związku między obserwowanymi zdarzeniami losowymi, które łączy jedynie wspólny czas wystąpienia. Podobnie podczas codziennych, prostych czynności, takich jak porządki w domu lub spacer rozmyślamy o rzeczach, które już się zdarzyły lub które dopiero mają nadejść, ponieważ takie treści tworzą historię opartą na zależnościach. Rzadko jednak koncentrujemy się na zapachu powietrza podczas przechadzki lub do-

${ }^{2}$ M. Adamik, Rozwijanie wewnętrznej wolności. Trening uważności jako praktyka samodystansowania się w świetle teorii Viktora Frankla, https:/ / www.researchgate.net/ publication/331330593_ Rozwijanie_wewnetrznej_wolnosci_Trening_uwaznosci_jako_praktyka_samodystansowania_ sie_w_swietle_teorii_Viktora_Frankla [dostęp: 13.05.2020].

${ }^{3}$ Njanaponiki, Thera, za: D. Goleman, Medytujacy umyst, Bydgoszcz 1998, s. 50.

${ }^{4}$ J. Kabat-Zinn, Mindfulness Based Interventions in Context: Past, Present, and Future, Clinical Psychology Sciense and Practice, 2003, 10, 2, [data dostępu: 13.05.2020] https://onlinelibrary. wiley.com/doi/full/10.1093/clipsy.bpg016

${ }^{5}$ D.J. Siegel, Uważność. Trening pokonywania codziennych trudności, Warszawa 2011, s. 49.

${ }^{6}$ M. Adamik, Rozwijanie wewnętrznej wolności.

7 S. Hayes, S. Smith, W pułapce myśli. Jak skutecznie poradzić sobie z depresja, stresem i lękiem, przekł. A. Wojciechowski, Sopot 2019.

${ }^{8}$ D. Kahneman, Pułapki myślenia. O myśleniu szybkim i wolnym, przekł. P. Szymczak, Poznań 2012. 
znaniach płynących z zanurzania rąk w wodzie, na przykład podczas mycia naczyń, ponieważ odnosi się to do wyizolowanego doświadczenia. Trudność praktyki uważności wynika również z tego, że nasz umysł w toku ewolucji ukształtował się tak, aby nieustannie rozmyślać o tym, co na zewnątrz, a nie o tym, co wewnątrz. Nasze myśli zwykle krążą wokół naszych relacji i interakcji z otoczeniem, co pozwala nam adekwatnie dostosować się do jego wymogów. Zauważenie własnych myśli i doznań bywa rzeczą dużo trudniejszą. Z ewolucyjnego punktu widzenia, koncentracja na zewnętrznych aspektach może być przydatna, szczególnie w sytuacjach, w których dochodzi do zaspokojenia własnych potrzeb lub/i uniknięcia zagrożenia. Nasze myśli same w sobie nie są odbiciem rzeczywistości, a jedynie ją opisują i interpretują; w dodatku w bardzo subiektywny i zależny od całości aparatu psychicznego sposób. Nie stanowią więc przedmiotu poznania, a narzędzie służące temu celowi, równocześnie automatycznie i poza kontrolą świadomości łącząc opis rzeczywistości z motywacjami wewnętrznymi osoby 9 .

Uważność kieruje naszą świadomość na obecne doświadczenia. Zwracamy się wtedy ku temu, co aktualnie odczuwamy i co pojawia się w obszarze naszych doznań fizjologicznych i emocjonalnych. Ponieważ jednak oparta jest na otwartości i ciekawości, „odbarcza” nas od oceniania. Możemy wtedy zauważyć, że doświadczaną przez nas aktualnie emocją jest smutek lub złość. Pozwala to na dostrzeżenie i poznanie własnych uczuć, stanów i potrzeb, bez odnoszenia się do tego, co oczekiwane lub co leży w zakresie konwenansów narzucanych przez otoczenie. Na podstawie takiej umiejętności poznania siebie można podejmować różne decyzje: czasem nastawione bardziej na zachowanie dobrych relacji z innymi, czasem na zaspokojenie potrzeb swojego ciała lub działające na rzecz innych obszarów naszego życia. Najważniejszą wartością niesioną przez praktykę uważności jest jednak to, że wybory te mogą być wyborami świadomymi.

\section{Praktykowanie uważności}

Trening mindfulness, zarówno w pracy z dziećmi, jak i osobami dorosłymi, stanowi pewien wstęp do praktyki uważności w życiu codziennym. Sam udział w ćwiczeniach nakierowanych na rozwój uważności może przynieść jedynie krótkotrwale efekty $\mathrm{w}$ postaci chwilowego obniżenia napięcia emocjonalnego, chociaż i to nie musi się wydarzyćc ${ }^{10}$. Główną wartością treningu mindfulness jest nauczenie się kierowania swoją uwagą w sposób nie oceniający ani zauważanych treści, ani samego przebiegu tego działania tak, by moż-

\footnotetext{
9 Tamże.

${ }^{10} \mathrm{~S}$. Hayes, S. Smith, W pułapce myśli.
} 
na było zgeneralizować bycie uważnym na czynności życia codziennego. Celem jest więc wyrobienie nawyku bycia bardziej świadomym. Taka zdolność pozwala na zauważanie własnych potrzeb, emocji, czy stanów fizjologicznych oraz podejmowanie właściwych reakcji uwzględniających wewnętrzne sygnały, a nie tylko wymagania i oczekiwania otoczenia zewnętrznego. Pozwala to na planowanie dłuższej aktywności według indywidualnych możliwości, projektowanie działań adekwatnych do wyznawanych wartości, czy też na skuteczniejszą samoregulację emocjonalną. Aspekt braku oceny umożliwia także obserwowanie swoich trudniejszych odczuć, takich jak cierpienie, złość, smutek lub wstyd. Dzięki temu możliwe stanie się ich uświadomienie, pomieszczenie i radzenie sobie $\mathrm{z}$ nimi.

Praktykowanie uważności samo w sobie może stanowić trening funkcji uwagi. Pozwala to na wydłużanie czasu koncentracji oraz na łatwiejszy powrót do realizowanego zadania po przerwie spowodowanej działaniem dystraktora $^{11}$. Badania Felvera, Hoyos, Tezanos i Singh ${ }^{12}$ wskazują na rozwój selektywności uwagowej, a analizy Dębskiej i Jacennik ${ }^{13}$ - na poprawę działania funkcji wykonawczych wskutek trenowania mindfulness. Ćwiczenie uważności pozwala także obserwować własne funkcjonowanie poznawcze i wyciągać na tej podstawie wnioski do dalszej pracy, lepiej dopasowując jej przebieg do posiadanych możliwości. Jednocześnie, trening uważności umożliwia pasywne hamowanie oddziaływania niepożądanych myśli poprzez zauważenie ich i zaprzestanie dalszego kierowania uwagi na ich występowanie $^{14}$. Rozwojowi ulegają więc również funkcje metapoznawcze.

Praktyka uważności zawiera w sobie także komponent wzmacniania samoregulacji emocjonalnej. Odczuwane przez nas emocje nie pojawiają się samoczynnie, a jako skutek zaktywizowania konkretnych przekonań i myśli. Uruchamiają one program działania, który często otrzymuje wagę priorytetu, a więc hamuje dotychczas kontynuowaną działalność ${ }^{10}$. Nie można w sposób całkowicie skuteczny zablokować odczuwania określonych emocji, a jedynie tymczasowo je zignorować. W dłuższej perspektywie stanowi to obciążenie dla funkcjonowania psychologicznego, podnosi poziom napięcia oraz łatwo może doprowadzić do zaniedbania własnych potrzeb. W podejściu uważności dużą wage przykłada się do zauważania pojawiających się doznań emocjonalnych. Brak oceny i ciekawość ułatwiają zrozumienie ich przyczyn, czyli zauważenie myśli leżących u podstaw

11 A. Dębska, B. Jacennik, Programy nauczania uważności dla dzieci i młodzieży - z perspektywy szkolnictwa polskiego, Przegląd Badań Edukacyjnych, 2016, 23(2).

${ }_{12}$ J. Felver i in., A Systematic Review of Mindfulness-Based Interventions for Youth in School Settings, Mindfulness, 2015, 2.

13 A. Dębska, B. Jacennik, Programy nauczania uważności dla dzieci i młodzieży.

${ }_{14}$ T. Jankowski, P. Holas, Poznawcze mechanizmy uważności i jej zastosowanie w psychoterapii, Studia Psychologiczne, 2009, 47, 4. 
ich aktywowania. Mindfulness zakłada jednak, że myśli te także nie podlegają ocenie. Są jedynie naszym sposobem rozumienia tej rzeczywistości. Jeżeli więc przed trudnym sprawdzianem pojawia się uczucie lęku, można je odnieść do wywołującej je myśli, na przykład "dostanę słabą ocenę". Tę myśl warto zauważyć, pamiętając równocześnie, że stanowi ona jedynie opis jednego z możliwych scenariuszy przyszłości. Wtedy, jak piszą Wahl i Mazurkiewicz ${ }^{15}$, łatwo można przenieść swoją uwagę z odczuwanego lęku na myśli oraz zrozumieć, że myśli są zależne od nas. Tego typu podejście charakterystyczne jest między innymi dla koncepcji poznawczo-behawioralnych, a więc na przykład Racjonalnej Terapii Zachowania.

Powoduje to zwiększenie dystansu psychologicznego do odczuwanych emocji i obniża poziom napięcia wywołanego ich pojawieniem się. Nie mamy więc do czynienia z unikaniem doświadczeń, a z możliwością pełnego włączenia ich w system wiedzy o sobie. Stanowi to ważne źródło służące pogłębieniu zrozumienia siebie. Wśród zagranicznych badań nad wpływem treningu uważności na funkcjonowanie emocjonalne uczniów wyraźnie zaznacza się wpływ tego rodzaju oddziaływań na obniżenie poziomu lęku i objawów związanych z depresją oraz wzrost doświadczanych emocji pozytywnych ${ }^{16}$.

Jak wskazuje Muskała ${ }^{17}$, jeden z widocznych efektów stosowania treningów uważności stanowi obniżenie wskaźnika wrogości. Jest to związane $z$ poprawą $w$ obrębie komunikacji własnych potrzeb i emocji oraz ze wzrostem empatii. Ponieważ uważność ułatwia proces defuzji od własnych myśli i przekonań, zwiększa się możliwość regulacji zachowania. Dzięki temu częściej działania impulsywne zostają zastąpione reakcjami mającymi u źródła refleksję nad własną aktywnością, a wybór zachowań jest bardziej świadomy i mniej ograniczony chwilowym stanem emocjonalnym. Badania naukowe także potwierdzają zmniejszenie liczby zachowań agresywnych $\mathrm{u}$ dzieci i młodzieży uczestniczących $\mathrm{w}$ treningu mindfulness oraz wzrost kompetencji emocjonalno-społecznych $\mathrm{w}$ tej grupie ${ }^{18}$. Ponadto, ze względu na możliwość przeprowadzania treningu uważności w zespole, wzrasta poziom integracji grupowej oraz uwspólniania celów. Rozwój funkcji uwagowych jest powiązany z funkcjonowaniem społecznym i większą czujnością na sygnały płynące ze strony innych osób ${ }^{19}$. Dzięki temu można uniknąć

${ }^{15}$ J. Wahl, M. Mazurkiewicz, Uważność w życiu i pracy - jak wptywa na zdrowie psychiczne i fizyczne oraz funkcjonowanie organizacji, Be Mindful, 2019, 1 .

J. Felver i in., A Systematic Review of Mindfulness-Based Interventions.

16 Tamże.

${ }_{17}$ M. Muskała, Trening uważności w oddziatywaniach resocjalizacyjnych. Kontekst teoretyczny, Resocjalizacja Polska, 2018, 15.

${ }_{18}$ J. Felver i in., A Systematic Review of Mindfulness-Based Interventions.

19 E. Nęcka, Procesy uwagi, [w:] Psychologia. Podręcznik akademicki. Psychologia ogólna, red. J. Strelau, Gdańsk 2006. 
nieporozumień wynikających z niewłaściwego odczytania intencji drugiego człowieka. Z kolei, wzrost zrozumienia motywów kierujących zachowaniem innych wiąże się ze zwiększeniem ogólnej empatii, mniejszą wrogością i wyższym poziomem odczuwanej sympatii. Co za tym postępuje, łatwiej nam odebrać zachowania innych jako pozytywne i nie kierowane przeciwko nam, a jedynie jako wyraz wewnętrznych potrzeb i uczuć tych osób. Przyjęcie takiej perspektywy wpływa więc na ogólne nastawienie wobec innych ludzi.

Podejście uważności można także odnieść do procesów uczenia się. Ponieważ zakłada ono bycie "tu i teraz", ułatwia koncentrację uwagi na aktualnie wykonywanym działaniu. W efekcie zmniejsza się oddziaływanie dystraktorów wewnętrznych, takich jak na przykład rozmyślanie nad ilością pracy czy liczbą i zakresem oczekiwań społecznych. Ponieważ taki sposób funkcjonowania nie zawiera elementu oceniania, zwiększa także kreatywne podejście do wykonywanych czynności. Często stres podczas pracy i nauki wiąże się z pojawianiem obaw o niewłaściwe wykonanie zadania lub niewywiązanie się z niego na czas. Może to usztywniać procedury zachowania nakierowane na realizowanie obowiązków. Jeżeli jednak takie obawy zostaną odniesione do konkretnych stojących za nimi myśli, a te znowu zostaną zauważone jako wytwór umysłu, a nie opis rzeczywistości, możliwe staje się obniżenie napięcia emocjonalnego podczas pracy i efektywniejsze wykorzystanie czasu na nią przeznaczonego. Równocześnie może to wpłynąć na bardziej swobodne i otwarte traktowanie nowo powstających pomysłów i idei. Sprzyja to kreatywnemu podejściu do rozwiązywania problemów.

Kolejnym czynnikiem silnie związanym z praktyką uważności jest wzrost refleksyjności. Lepsza analiza własnych procesów poznawczych i emocjonalnych umożliwia wyciąganie wniosków dotyczących kierunku i efektywności działań. Jak podają Łukaszewski i Doliński ${ }^{20}$, znajomość własnych możliwości i potrzeb ułatwia utrzymanie optymalnego poziomu pobudzenia potrzebnego do realizacji bieżących zadań, zgodnie z prawem Yerkesa-Dodsona. Następuje to $\mathrm{w}$ zgodzie $\mathrm{z}$ indywidualnym poziomem pobudzenia korowego, regulowanego przez struktury podkorowe zgodnie z teorią aktywacji Eysnecka ${ }^{21}$. Dzięki temu działalność staje się bardziej efektywna, ale także mniej obciążająca i odczuwana jako bardziej satysfakcjonująca dla osoby. Aktywny wpływ na budowanie własnej wiedzy, zamiast działania automatycznego i podporządkowanego schematom, stanowi właśnie podstawę funkcjonowania opartego na refleksyjności ${ }^{22}$. Nie

${ }^{20}$ W. Łukaszewski, D. Doliński, Mechanizmy leżące u podstaw motywacji, [w:] Tamże.

${ }^{21}$ J. Strelau, Osobowość jako zespót cech, [w:] Tamże, s. 535.

22 A. Perkowska-Klejman, Osądzanie refleksyjne - ocena intelektualnego rozwoju uczniów, studentów i absolwentów, Ruch Pedagogiczny, 2014, 4. 
chodzi przy tym, aby zawsze i wszędzie być w pełni uważnym, ale by móc uruchomić uważność $\mathrm{w}$ chwilach, kiedy będzie nam ona potrzebna tak, by umożliwić pełne, bogate i spełnione życie ${ }^{23}$.

\section{Trening uważności w pracy z dziećmi i młodzieżą}

Wprowadzanie tegoż treningu wymaga dopasowania oddziaływań do możliwości rozwojowych poszczególnych grup wiekowych. Tego typu zajęcia można wprowadzać już na poziomie wieku przedszkolnego, a więc w grupie pomiędzy 4. a 6. r.ż. Poziom rozwoju fizycznego cechuje wówczas znaczna samodzielność i silny wzrost ruchliwości, przy jednoczesnym wyższym poziomie kontroli ruchu ${ }^{24}$. Równocześnie jednak myślenie $\mathrm{w}$ wieku przedszkolnym znajduje się jeszcze na poziomie prelogicznym, więc wprowadzanie ćwiczeń opartych na samoobserwacji procesów umysłowych i wyciąganych z niej wniosków nie jest wskazane. Można jednak wprowadzać techniki ćwiczenia uważności odnoszące się do ćwiczeń fizycznych. Jeżeli to możliwe, warto wówczas uatrakcyjniać tego typu treningi o różnego rodzaju rekwizyty. Mogą to być ćwiczenia oddechowe z użyciem torebki papierowej lub piłki magicznej. Przydatne może być także odwołanie się do wyobraźni w ćwiczeniach typu: uważne chodzenie na przykład ,jak po lepkim błocie” lub „,jak po gorącym piasku". Dzięki temu dziecko rozwija poszczególne funkcje uwagi poprzez kierowanie je na swój ruch czy rytm oddechu. Jednocześnie uwaga kierowana jest do wewnątrz, a więc na funkcjonowanie swojego organizmu. Stanowi to wstęp do dalszego rozwoju umiejętności obserwacji siebie. Przy tym, forma zabawy, która jest główną aktywnością dzieci w wieku przedszkolnym, powoduje wzrost motywacji do wykonywanych ćwiczeń i uczucie przyjemności $\mathrm{z}$ uczestnictwa $\mathrm{w}$ treningu. Metoda obserwacji własnych ruchów czy oddechu nie jest nakierowana na ich ocenę i również wytwarza nawyk samoobserwacji bez osądzania. $W$ pracy $\mathrm{z}$ dziećmi $\mathrm{w}$ wieku przedszkolnym warto zwrócić uwagę na krótszy czas koncentracji uwagi oraz na obniżoną selektywność uwagową. Obydwa te czynniki będą powodowały, że ćwiczenia z dziedziny mindfulness nie będą mogły trwać zbyt długo. Ponadto, dziecko $\mathrm{w}$ tym wieku $\mathrm{w}$ większym stopniu będzie rozpraszało się pod wpływem dystraktorów zarówno o charakterze zewnętrznym, jak i wewnętrznym. Można wykorzystać ten fakt do wprowadzania postawy opartej na samym wykonywaniu ćwiczeń z zakresu uważności, a nie na rezultacie, a więc na działanie $\mathrm{w}$ stanie paratelicznym, a nie w stanie telicznym, co jest zbieżne z typową dla tego okresu rozwojowego formą aktywności.

${ }^{23}$ R. Harris, Zrozumieć ACT.

${ }^{24}$ B. Harwas-Napierała, J. Trempała (red.), Psychologia rozwoju człowieka. Charakterystyka okresów życia człowieka, Warszawa 2007. 
W okresie późnego dzieciństwa (7-10/12 r.ż.) coraz bardziej możliwe staje się wprowadzanie technik bezpośrednio odwołujących się do funkcji poznawczych i metapoznawczych. Uwaga dziecka zmienia swój charakter z mimowolnego na dowolny. Nie podąża więc już jedynie za bodźcami pojawiającymi się w jej polu, ale może być intencjonalnie kierowana na pożądaną aktywność lub wybrany bodziec. Zyskuje ona także funkcję podległą wobec struktury danej aktywności poznawczej oraz jej celu ${ }^{25}$. Długość czasu koncentracji uwagi również ulega ciągłemu wydłużaniu się. Zmianom podlega charakter pamięci, która staje się coraz bardziej logiczna i związana ze zrozumieniem treści zadania, a nie tylko mechanicznym zapamiętywaniem sekwencji. Koniec wieku szkolnego wieńczy rozwój metapamięci, a więc zbioru przekonań na temat pamięci oraz skutecznego posługiwania się nią ${ }^{26}$. Także myślenie wchodzi w nowy wymiar logiczny, dzięki czemu możliwa staje się analiza związków przyczynowo-skutkowych. Nadal warto więc stosować techniki oparte na pracy z ciałem, $\mathrm{w}$ tym ćwiczenia oddechowe, ale też bardziej dostępne staje się obserwowanie pojawiających się myśli i łączenie ich w związki przyczynowo-skutkowe z doświadczanymi emocjami. Należy jednak zawsze mieć na uwadze indywidualne możliwości dziecka i do nich dopasowywać oddziaływania.

W odniesieniu do wczesnej adolescencji (między ok. 10/12. a 16/17. r.ż. $)^{27}$ należy uwzględnić z jednej strony możliwości poznawcze, a z drugiej - typowe cechy emocjonalności charakteryzujące tę grupę wiekową. Funkcjonowanie poznawcze nastolatka odznacza się dużym subiektywizmem i idealizmem, ale także zwiększającą się zdolnością myślenia hipotetycznego. Równocześnie, zmiany w funkcjonowaniu układu hormonalnego powodują labilność i ambiwalencję emocjonalną. Opisane zjawiska rozwojowe można uwzględnić w zajęciach o charakterze treningu uważności poprzez wykorzystanie subiektywizmu i koncentracji na sobie do ćwiczenia samoobserwacji i śledzenia przebiegu procesów intrapsychicznych. Poza tym, okres wczesnej adolescencji to czas silnej identyfikacji z grupą rówieśniczą. Zajęcia uwzględniające techniki pracy grupowej mogą ułatwiać uczestnictwo w nich dzięki poczuciu wsparcia grupy, a wymiana doświadczeń i przemyśleń może stanowić bodziec do rozwoju zdolności empatii. Dzięki takim zabiegom naturalne procesy rozwojowe oraz oddziaływania psychologiczne będą się wzajemnie wspierały i uzupełniały.

${ }^{25}$ R. Stefańska-Klar, Późne dzieciństwo. Młodszy wiek szkolny, [w:] Tamże, s. 134.

${ }^{26}$ J. Trempała, Rozwój poznawczy, [w:] Psychologia rozwoju człowieka. Rozwój funkcji psychicznych, red. B. Harwas-Napierała, J. Trempała, Warszawa 2006, s. 36.

${ }_{27}$ M. Bardziejewska, Okres dorastania. Jak rozpoznać potencjał nastolatków? [w:] Psychologiczne portrety człowieka. Praktyczna psychologia rozwojowa, red. A.I. Brzezińska, Sopot 2004, s. 345. 
Późna adolescencja obejmuje wiek od 16/17 lat do 20. r.ż. ${ }^{28}$ i niesie ze sobą dalszy rozwój myślenia w obszarze operacji formalnych oraz ustabilizowanie się rozchwianych do tej pory emocji i nastrojów. Dochodzi do coraz częstszych konfrontacji własnych postaw i przekonań ze światem zewnętrznym, co powoduje spadek poznawczej pewności własnych sądów. Następuje też wzrost zainteresowania wartościami moralnymi. Trening uważności stanowi $\mathrm{w}$ tym okresie wsparcie $\mathrm{w}$ przyglądaniu się własnym potrzebom i emocjom w konfrontacji ze światem zewnętrznym. Pozwala także zwiększyć defuzję od własnych przekonań. Może to ułatwić rozpoznanie swoich potrzeb i wartości kierujących wyborami życiowymi oraz dalszy wzrost empatii i zrozumienia motywacji innych. Dzięki temu wybór własnych zachowań staje się bardziej adekwatny do oczekiwań zewnętrznych, ale przede wszystkim silniej dopasowany do wewnętrznych potrzeb adolescenta, który właśnie poszukuje swojego miejsca w świecie.

Jak wynika z powyższego opisu, korzyści płynące z treningu uważności prowadzonego wśród dzieci i młodzieży w różnym wieku mieszczą się w wielu obszarach funkcjonowania. Trening uważności można dostosować do każdego etapu rozwoju w taki sposób, aby rozwój ten był wspierany, a zajęcia atrakcyjne i przyjemne dla uczestników. Zajęcia grupowe w obszarze treningu uważności mogą także stanowić znaczący element wzmacniania integracji grupowej.

Bardzo istotny jest także wpływ uważności na stan zdrowia. Ze względu na zwiększony odbiór własnych potrzeb i sygnałów wysyłanych przez ciało, łatwiej dopasować zachowania do potrzeb wewnętrznych, a nie zewnętrznych pobudek oraz zmienić codzienne nawyki na zdrowsze. Jak twierdzi Kahneman ${ }^{29}$, ludzie mają naturalną skłonność do podejmowania decyzji w sposób mało refleksyjny. Często dzieje się to na zasadzie wyuczonych nawyków. Wzrost refleksyjności wpływa na przełamanie tych tendencji. Procesy samoregulacji zostają uruchomione, a ich działanie sprzyja zachowaniu wewnętrznej homeostazy. Takie zagadnienia, jak zdrowe odżywianie niezależne od występujących w otoczeniu pokus czy regularna aktywność fizyczna wymagają od osoby podjęcia świadomej decyzji z uwzględnieniem wartości, jaką jest własne zdrowie. Ponadto, same ćwiczenia z obszaru uważności wykazują pozytywny związek z utrzymaniem prawidłowego ciśnienia $\mathrm{krwi}^{30}$ oraz spadek problemów $z$ bezsennością ${ }^{31}$. Bardzo istotnym obszarem funkcjono-

${ }^{28}$ Tamże.

29 D. Kahneman, Pułapki myślenia.

${ }^{30}$ A. Błaszczak, Wpływ Treningu Redukcji Stresu opartego na uważności (MBSR) na zdrowie fizyczne, Annales Universitatis Mariae Curie-Skłodowska, Sectio J - Paedagogia-Psychologia, 2018, 31(1).

${ }^{31}$ J. Felver i in., A Systematic Review of Mindfulness-Based Interventions. 
wania, który znajduje się pod pozytywnym wpływem treningów mindfulness jest także zdrowie psychiczne. Felver, Hoyos, Tezanos i Singh ${ }^{32}$ wskazują, że u uczniów, którzy korzystali z tego rodzaju zajęć zanotowano zmniejszony poziom lęku uogólnionego i fobii, obniżenie wskaźników depresji i zmniejszenie częstotliwości występowania myśli samobójczych.

\section{Mindfulness w szkole - możliwości i ograniczenia}

Jednym z obszarów funkcjonowania dziecka, który może podlegać oddziaływaniu technik mindfulness, jest przestrzeń edukacji. Ponieważ techniki uważności ułatwiają rozwój funkcji poznawczych i metapoznawczych, ich stosowanie może poprawiać wydajność procesu nauczania, wpływać na organizację nauki oraz przekładać się na ogólne funkcjonowanie szkolne $\mathrm{w}$ zakresie zwiększania poziomu wiedzy, kompetencji, a tym samym poprawy ocen szkolnych. Wzrost zdolności do koncentracji uwagi i zarządzania pamięcią zanotowano $\mathrm{w}$ badaniach nad wpływem wprowadzania zajęć z uważności do szkół w Stanach Zjednoczonych i krajach zachodniej Europy $^{33}$. Dzięki lepszemu zarządzaniu własną aktywnością na polu nauki aktywuje się także bardziej korzystne procesy motywacyjne. Lepsze poznanie i zrozumienie własnych możliwości i potrzeb oraz dopasowanie do nich sposobu wykonywania działań obniża poziom odczuwanej frustracji.

Nauka i związane z nią procesy poznawcze oraz motywacyjne nie są jedynym obszarem wpływającym na szkolne i pozaszkolne funkcjonowanie dzieci i młodzieży, którego działanie podlega korzystnym zmianom pod wpływem treningu mindfulness. Kolejnym z nich jest także, wspomniane wcześniej, funkcjonowanie społeczne. Badania Felver, Hoyos, Tezanos i Singh ${ }^{34}$ wykazują pozytywny efekt $w$ dziedzinie kontroli zachowania i agresji interpersonalnej. Spadek zachowań impulsywnych i agresywnych oraz wzrost optymizmu umożliwiają zwiększenie integracji i współpracy w grupie oraz zmniejszenie liczby konfliktów. Powoduje to wzrost pozytywnych doświadczeń w obszarze relacji społecznych i postrzeganie ich jako bardziej przyjemne i pożądane. Natomiast, rozwój empatii ułatwia zrozumienie intencji i potrzeb innych, dzięki czemu relacje stają się głębsze i oparte na wzajemnym szacunku. Badania opisywane przez Syper-Jędrzejak i Bednarską-Wnuk ${ }^{35}$ dowodzą istnienia

32 Tamże.

${ }_{33}$ Tamże; C. Zenner, S. Herrnleben-Kurz, H. Walach, Mindfulness-based interventions in schools - a systematic review and meta-analysis, Frontiers in Psychology, 2014, 5.

${ }^{34}$ J. Felver i in., A Systematic Review of Mindfulness-Based Interventions.

${ }_{35}$ M. Syper-Jędrzejak, I. Bednarska-Wnuk, Znaczenie mindfulness $w$ miejscu pracy - możliwości pobudzania uważności pracowników, E-mentor, 2019, 79(2) http://www.e-mentor.edu.pl/ artykul/index/numer/79/id/1413 [data dostępu: 09.05.2020]. 
bezpośredniego związku pomiędzy uważnością a inteligencją emocjonalną, co z kolei pozytywnie rzutuje na relacje społeczne.

Innym ważnym polem wykorzystywania podejścia uważności $\mathrm{w}$ pracy z uczniami jest rozwój ich autonomii i niezależności działania. Ponieważ minfulness skłania ku organizacji własnych działań i dopasowywaniu ich do indywidualnych potrzeb oraz możliwości, jest ono także sprzymierzeńcem $\mathrm{w}$ rozwoju twórczości. Takie postawy w środowisku szkolnym ułatwiają wykorzystanie potencjału ucznia w kierunku osiągania przez niego celów edukacyjnych. Jednocześnie jednak mogą same w sobie stanowić przyczynę nieporozumień i trudności. Ponieważ nauka w polskiej szkole nadal oparta jest w przeważającym stopniu na ujednoliceniu oddziaływań i hierarchicznej strukturze społecznej ${ }^{36}$, autonomiczne podejście do działań wykonywanych na lekcji może być postrzegane jako utrudnienie w pracy nauczyciela. O ile bowiem sama niezależność myślenia w rozwiązywaniu zadań może stanowić przyczynę sukcesów edukacyjnych ucznia, o tyle autonomia postaw społecznych i przekonań potencjalnie może zostać odebrana jako podważanie autorytetu nauczyciela lub próba wykazania jego niewiedzy. W tym wypadku jednak możliwym czynnikiem zapobiegającym tego typu sytuacjom jest zaproszenie do tego typu treningów nauczycieli.

Pomimo że, jak wspomniano powyżej, techniki uważności mogą znaleźć zastosowanie $\mathrm{w}$ środowisku szkolnym, to jednak polska szkoła ma pewne swoje charakterystyczne cechy, które mogą utrudniać prowadzanie zajęć z uważności na podobnym poziomie, jak ma to miejsce $w$ innych krajach. Jedną z nich jest łączenie mindfulness, szczególnie ćwiczeń oddechowych i technik o charakterze medytacyjnym, z buddyzmem. Pomimo rekomendacji wielu przedstawicieli Kościoła katolickiego wprowadzania zajęć z uważności do szkół oraz istnienia ruchów medytacji chrześcijańskiej ${ }^{37}$, techniki mindfulness nadal budzą niepokój i niechęć w oświacie. Jednocześnie warto zaznaczyć, że certyfikowane szkolenia prowadzone w podejściu uważności mają charakter całkowicie świecki i nie są powiązane z ruchami religijnymi.

Stosowanie omawianych oddziaływań może budzić obawy z jeszcze jednego powodu. Jest ono oparte na otwartej i szczerej komunikacji. Taki rodzaj relacji z uczniem wymaga od samego nauczyciela postawy otwartości i zrozumienia. Założeniem podejścia opartego na uważności jest zresztą to, że uczyć go może jedynie osoba sama je praktykująca. Skutkuje to więc ponownie potrzebą prowadzenia kursów mindfulness dla grupy nauczycieli. Potwierdzeniem tego mogłyby być badania odnoszące się do diagnozy kompetencji

${ }^{36}$ A. Suchocka, Przemoc symboliczna jako element ukrytego programu ksztatcenia polskiej szkoty, Zeszyty Naukowe Akademii Marynarki Wojennej, 2011, 4(187), s. 297.

37 S. Radoń, Uważność jako neuro-psycho-biologiczna próba zdefiniowania fenomenu duchowości, Studia Religiologica, 2013, 46(3). 
społecznych nauczycieli autorstwa Piorunek i Werner ${ }^{38}$. Okazuje się, iż awans zawodowy nauczycieli nie koreluje z (oczekiwanym) wzrostem kompetencji społecznych. Ujemny związek wieku z poziomem kompetencji społecznych nasuwa wątpliwości co do efektywności działania systemu szkolnictwa zarówno w zakresie wsparcia nauczycieli, jak też systemu ich awansowania, a także jakości i diagnozy potrzeb tej grupy zawodowej. Zaledwie 18,5\% nauczycieli w badaniu tym przejawiało kompetencje kooperacyjne na wysokim poziomie. A zawód nauczyciela, jak rzadko który, wymaga właśnie umiejętności współpracy z ludźmi. F. Delamare Le Deist i J. Winteron ${ }^{39}$ opracowali holistyczny model kompetencji, w skład którego wchodzą kompetencje poznawcze, funkcjonalne, społeczne i metakompetencje. Pierwsze związane są ze sposobem odbierania, przetwarzania informacji; drugie dotyczą roli zawodowej i efektywności w jej obrębie; trzecie łączą się z funkcjonowaniem w relacjach interpersonalnych, natomiast czwarte, jak piszą Piorunek i Werner, „wiążą się zaś z możliwościami dokonywania pogłębionej refleksji i kreatywnego radzenia sobie $\mathrm{w}$ warunkach zmiany i niepewności ${ }^{40 \prime}$. Można założyć, iż mindfulness mógłby być jednym z narzędzi do zwiększenia kompetencji w tych czterech obszarach. Dotyczy to w szczególności współczesnych polskich nauczycieli, którzy pracują w sytuacji „permanentnej zmiany i niepewności”, związanej zarówno ze współczesną sytuacją epidemiologiczną (Covid-19) na świecie, ale także z naszą rodzimą trudną rzeczywistością, której wynikiem był ogólnopolski strajk tej grupy zawodowej.

Aby jednak nauczyciele chcieli skorzystać z takiej możliwości, potrzebne jest spełnienie kilku warunków. Pierwszy z nich stanowi sama świadomość istnienia tego typu podejścia i jego znaczenia dla edukacji. Drugim jest możliwość powszechnego dofinansowania szkoleń dla nauczycieli przez placówki oświatowe. Trzeci ważny element polega na przeanalizowaniu formy, w jakiej w ogóle podejście uważności mogłoby zostać implementowane do szkół.

Ze względu na standardową liczbę lekcji w planie, trudne byłoby wprowadzenie regularnych dodatkowych godzin przeznaczonych na sam trening uważności. Z drugiej strony, lekcje wychowawcze są niezbędne do realizowania dużej ilości treści zawartych między innymi w programach wychowawczo-profilaktycznych szkół. Być może, po przeszkoleniu nauczycieli oraz przeprowadzeniu krótkich kursów dla uczniów, można byłoby wprowadzić w szkołach sposób prowadzenia lekcji oparty na zasadach mindfulness.

${ }_{38}$ M. Piorunek, I. Werner, Kompetencje społeczne nauczycieli-diagnoza i pomocowe implikacje, Studia Edukacyjne, 2017, 44.

39 F. Delamare Le Deist, J. Winterton, Wath is competence? Human Resource Development International, 2005, 8, 1 .

${ }^{40}$ M. Piorunek, I. Werner, Kompetencje społeczne nauczycieli, s. 124. 
Dzięki temu podstawy takiego funkcjonowania mogłyby zostać włączone w działania szkoły, bez znaczącego wydłużania pobytu ucznia w placówce.

Pomimo wszystkich tych ograniczeń liczba potencjalnych korzyści płynących z praktyki uważności, zarówno dla funkcjonowania jednostki oświatowej, jak i samego ucznia czy nauczyciela, jest dość duża. Dlatego warto byłoby rozważyć sposób wprowadzenia jej do standardów funkcjonowania polskiej szkoły.

\section{Zakończenie}

Jak zaznaczają Hayes i Smith ${ }^{41}$, podejście mindfulness zakłada, że ćwiczenia uważności wykonuje się nie w celu relaksacji i poprawy samopoczucia, a w celu poznania siebie. Dlatego praktykuje się je nie tylko będąc w dobrym nastroju, ale w takim, jakim się aktualnie jest. Daje to możliwość poznania swoich emocji i potrzeb, a nie ich unikania. Pozwala to na radzenie sobie z własnymi emocjami, szczególnie tymi „problemowymi” oraz sytuacjami trudnymi czy kryzysowymi. Jest to niezwykle ważne zarówno dla dzieci i młodzieży, a więc uczniów, jak też dla nauczycieli. Jednak, jak zaznaczono powyżej, aby treningi te przyniosły zamierzony skutek, powinny być prowadzone przez osoby rzetelnie do tego przygotowane, dysponujące zarówno wiedzą z tego obszaru, jak też niezbędnymi kompetencjami i umiejętnościami. Nie wystarczy także przeprowadzenie osobnej lekcji teoretycznej poświęconej tej tematyce. Istotne jest zrozumienie korzyści płynących z mindfulness oraz praktykowanie jej w codziennym życiu. Wówczas mamy szansę na zwiększenie świadomości odnoszącej się zarówno do własnych procesów wewnętrznych, jak i funkcjonowania społecznego. Praktykowanie uważności może być zatem jednym z kierunków pomocy polskiej szkole w radzeniu sobie z wyzwaniami i trudnościami.

\section{BIBLIOGRAFIA}

Adamik M., Rozwijanie wewnętrznej wolności. Trening uważności jako praktyka samodystansowania się w świetle teorii Viktora Frankla, [data dostępu: 13.05.2020] https://www. researchgate.net/publication/331330593_Rozwijanie_wewnetrznej_wolnosci_Trening_uwaznosci_jako_praktyka_samodystansowania_sie_w_swietle_teorii_Viktora_Frankla

Błaszczak A., Wpływ Treningu Redukcji Stresu opartego na uważności (MBSR) na zdrowie fizyczne, Annales Universitatis Mariae Curie-Skłodowska, Sectio J - Paedagogia-Psychologia, 2018, 31, 1.

\footnotetext{
${ }^{41}$ S. Hayes, S. Smith, W pułapce myśli.
} 
Brzezińska A.I. (red.), Psychologiczne portrety człowieka. Praktyczna psychologia rozwojowa, Gdańskie Wydawnictwo Psychologiczne, Sopot 2004.

Creating an Environment for Emotional and Social Well-Being An important responsibility of a Health-Promoting and Child Friendly School, The World Health Organization's Information Series on School Health, 10, [data dostępu: 08.05.2020r.] https://www.who. int/school_youth_health/media/en/sch_childfriendly_03.pdf

Delamare Le Deist F.D., Winterton J., What Is Competence? Human Resource Development International, 2005, 8, 1.

Dębska A., Jacennik B., Programy nauczania uważności dla dzieci i młodzieży - z perspektywy szkolnictwa polskiego, Przegląd Badań Edukacyjnych, 2016, 23, 2.

Dobkin P.L., Irving J.A., Amar S., For whom May Participation in a Mindfulness-Based Stress Reduction Program be Contraindicated? Mindfulness, 2012, 3.

Farias M., What is mindfulness - based therapy good for? Evidence, Limitations and Controversies, The Lanced Psychiatry, 2016, 3.

Felver J., Hoyos C., Tezanos K., Singh N., A Systematic Review of Mindfulness-Based Interventions for Youth in School Settings, Mindfulness, 2015, 2.

Goldin P., Gross J., Effects of Mindfulness-Based Stress Reduction (MBSR) on Emotion Regulation in Social Anxiety Disorder, Emotion, 2010, 10, 1.

Goleman D., Medytujacy umyst, Limbus, Bydgoszcz 1998.

Góralska R., Uważność: technika uczenia się czy droga wspierania (samo)rozwoju? Rocznik Andragogiczny, 2019, 26.

Harris R., Zrozumieć ACT. Terapia akceptacji i zaangażowania w praktyce, przekł. A. Sawicka-Chrapkowicz, Gdańskie Wydawnictwo Psychologiczne, Sopot 2017.

Harwas-Napierała B., Trempała J. (red.), Psychologia rozwoju człowieka. Rozwój funkcji psychicznych, Wydawnictwo Naukowe PWN, Warszawa 2006.

Harwas-Napierała B., Trempała J. (red.), Psychologia rozwoju człowieka. Charakterystyka okresów życia człowieka, Wydawnictwo Naukowe PWN, Warszawa 2007.

Hayes S., Smith S., W pułapce myśli. Jak skutecznie poradzić sobie z depresją, stresem i lękiem, przekł. A. Wojciechowski, Gdańskie Wydawnictwo Psychologiczne, Sopot 2019.

Jankowski T., Holas P., Poznawcze mechanizmy uważności $i$ jej zastosowanie w psychoterapii, Studia Psychologiczne, 2009, 47, 4.

Kabat-Zinn J., An Outpatient Program in Behavioral Medicine for Chronic Pain Patitens Based on the Practice of Mindfulness Meditation: Theoretical Considerations and Preliminary Results, Gen Hosp Psychiatry, 1982, 4, 1.

Kabat-Zinn J., Mindfulness-Based Interventions in Context: Past, Present and Future, Clinical Psychology Sciense and Practice, 2003, 10, 2, [data dostępu: 13.05.2020] https://onlinelibrary.wiley.com/doi/full/10.1093/clipsy.bpg016

Kahneman D, Pułapki myślenia. O myśleniu szybkim i wolnym, przekł. P. Szymczak, Media Rodzina, Poznań 2012.

Keye M., Pidgeon A., An Investigation of the Relationship between Resilience, Mindfulness, and Academic Self-Efficacy, Open Journal of Social Sciences, 2013, 6, 1.

Kołodziejczyk J., Agresja i przemoc w szkole. Konstruowanie programu przeciwdziałania agresji i przemocy w szkole, Niepubliczny Ośrodek Doskonalenia Nauczycieli SOPHIA, Kraków 2004.

Makaruk K., Dzieci się liczą. Raport o zagrożeniach bezpieczeństwa i rozwoju dzieci w Polsce, Dzieci się liczą, 2017, [data dostępu: 10.05.2020r.] https://fdds.pl/wp-content/ uploads/2017/07/dziecisielicza.pdf

Muskała M., Trening uważności w oddziatywaniach resocjalizacyjnych. Kontekst teoretyczny, Resocjalizacja Polska, 2018, 15. 
Perkowska-Klejman A., Osądzanie refleksyjne - ocena intelektualnego rozwoju uczniów, studentów i absolwentów, Ruch Pedagogiczny, 2014, 4.

Piorunek M., Werner I., Kompetencje społeczne nauczycieli - diagnoza i pomocowe implikacje, Studia Edukacyjne, 2017, 44.

Radoń S., Uważność jako neuro-psycho-biologiczna próba zdefiniowania fenomenu duchowości, Studia Religiologica, 2013, 46, 3.

Shonin E., Van Gordon W., Griffiths M.D., Are there risks associated with using mindfulness for the treatment of psychopathology? Clinical Practice, 2014, 11.

Siegel D.J., Uważność. Trening pokonywania codziennych trudności, Wydawnictwo Czarna Owca, Warszawa 2011.

Strelau J. (red.), Psychologia. Podręcznik akademicki. Psychologia ogólna, Gdańskie Wydawnictwo Psychologiczne, Gdańsk 2006.

Suchocka A., Przemoc symboliczna jako element ukrytego programu ksztatcenia polskiej szkoty, Zeszyty Naukowe Akademii Marynarki Wojenne, 2011, 187, 4.

Sun J., Mindfulness in Context: A Historical Discourse Analysis, Contemporary Buddhism, 2014, 15, 2.

Syper-Jędrzejak M., Bednarska-Wnuk I., Znaczenie mindfulness w miejscu pracy - możliwości pobudzania uważności pracowników, E-mentor 2019, 79, 2, [data dostępu: 09.05.2020r] http://www.e-mentor.edu.pl/artykul/index/numer/79/id/1413

Szymańska J., Ochrona zdrowia psychicznego dzieci i młodzieży w szkole, Ośrodek Rozwoju Edukacji, Warszawa 2014, [data dostępu: 07.05.2020r.] https:/ / bezpiecznaszkola.men. gov.pl

Tabak I., Zdrowie psychiczne dzieci i młodzieży. Wsparcie dzieci i młodzieży w pokonywaniu problemów, Studia BAS, 2014, 38, 2.

Wahl J., Mazurkiewicz M., Uważność w życiu i pracy - jak wpływa na zdrowie psychiczne i fizyczne oraz funkcjonowanie organizacji, Be Mindful, 2019, 1.

Zenner C., Herrnleben-Kurz S., Walach H., Mindfulness-based interventions in schools - a systematic review and meta-analysis, Frontiers in Psychology, 2014, 5.

Zolkoski S., Bullock L., Resilience in children and youth: A review, Children and Youth Services Review, 2012, 12. 